\title{
Obraz grzeczności na przykładzie reakcji na komplementy polskich i niemieckich studentów
}

\section{The concept of politeness exemplified by the Polish and German students' responses to compliments}

Violetta Frankowska

(Poznań)

\begin{abstract}
The growing interest in politeness phenomena clearly points to the importance of the issue in our life. Living with other people, one should consider other peoples' feelings and needs in order to be polite. Politeness is inevitably reflected in language and differs cross-culturally. It is common that certain forms of behavior are acceptable and appropriate in one culture, but not successful in the other one. The aim of this article is to present the concept of politeness on the basis of how Polish and German students respond to compliments. Such knowledge promotes harmonious intercultural relations.
\end{abstract}

\section{Wstęp}

W każdej kulturze istnieja pewne wzorce zachowań spolecznie oczekiwanych czy unikanych, uznawanych za grzeczne badź niegrzeczne. Fenomen grzeczności polega na jej dużym zróżnicowaniu kulturowym, co czyni ja wdzięcznym obiektem badań porównawczych. Co w jednej kulturze określa się mianem grzecznego zachowania, w innej może budzić odmienne odczucia, a w skrajnych przypadkach wywolać niezrozumienie czy też obrazić odbiorcę i doprowadzić do powstania konfliktu. 
Celem niniejszego artykulu jest ukazanie obrazu grzeczności, jaki wyłania się z reakcji na komplementy polskich oraz niemieckich studentów. Omówione zostaną wybrane podobieństwa i różnice w odbiorze tego aktu mowy w oparciu o teorię grzeczności Brown i Levinson.

Material będacy podstawą niniejszej analizy stanowią ankiety ${ }^{1}$ przeprowadze wśród 58 niemieckich studentów (30 studentek, 28 studentów) oraz 57 polskich studentów ( 29 studentek oraz 28 studentów) kierunków nielingwistycznych Uniwersytetu im. Adama Mickiewicza w Poznaniu, Uniwersytetu Ekonomicznego w Poznaniu oraz Uniwersytetu Bielefeld w wieku od 19 do 28 lat. Łaczna liczba wszystkich zebranych odpowiedzi wyniosla 345 (115 ankiet $\mathrm{x} 3$ sytuacje $=345$ reakcji na komplementy $)^{2}$, w tym: Niemcy: 174 $=123$ werbalne +51 niewerbalne / Polacy: $171=119$ werbalne + 52 niewerbalne. W analizie uwzględnione i przytoczone zostana rekcje werbalne oraz towarzyszace im komentarze respondentów. Poprzedzi ją krótkie wprowadzenie teoretyczne dotyczące wybranych teorii grzeczności oraz reakcji na komplementy.

\section{Grzeczność}

Grzeczność w powszechnym rozumieniu stanowi pewien zbiór przyjętych w danej społeczności regul, zasad postępowania, inaczej mówiąc dobre maniery czy takt, które nabywamy w procesie socjalizacji już od dziecka. Normy grzecznościowe stanowią wedhug Marcjanik (1992: 28)

1 Zadanie studentów polegało na zapisaniu werbalnych reakcji na komplementy występujące w trzech sytuacjach: Sytuacja nr 1: komplement $W$ tej nowej fryzurze wygladasz świetnie! wypowiedziany przez dobrą koleżankę. Sytuacja nr 2: komplement $W$ tej nowej fryzurze wygladasz świetnie! od nielubianej przez odbiorcę osoby. Sytuacja nr 3: komplement Dzisiaj wyglądasz pięknie! od koleżanki/kolegi z roku. Ankieta została sformułowana w języku polskim i niemieckim.

2 Należy tutaj zaznaczyć, że niektórzy studiujący nie podali dokładnej reakcji slownej, lecz dokonali opisu swoich emocji i zachowań. 
wyraz ogólnie przyjętych w spoleczeństwie sądów powinnościowych. Sądy te, w odróżnieniu od nakazów [...] wynikają z przekonań spolecznych co do stosowności bądź niestosowności określonych zachowań językowych (także niejęzykowych [...]) w zróżnicowanych pragmatycznie interakcjach (Marcjanik 1992: 28).

Podręczniki savoir-vivre'u przedstawiają zasady grzeczności werbalnej i niewerbalnej, zwracając uwagę na to, co jest grzeczne w sposób opisowy, ale raczej nie próbuja dokladniej definiować samego pojęcia grzeczności.

Można się czasem natknać na cytaty związane z metaforycznym obrazem grzeczności, które nierzadko daja sprzeczne prawdy o niej, jak np. „Höflichkeit ist wie ein Luftkissen: Es mag wohl nichts drin sein, aber sie mildert die Stöße des Lebens" (Grzeczność jest jak poduszka powietrzna: niby nic w niej nie ma, a jednak lagodzi ciosy życia) - Arthur Schopenhauer, „Es gibt ein Minimum von Unaufrichtigkeit, das von jedem verlangt werden kann: Höflichkeit" (Istnieje minimum nieszczerości, które wymaga się od każdego: grzeczność) - Hans Krailsheimer, czy też myśl Josepha Jouberta: „Höflichkeit ist die Blüte der Menschlichkeit. Wer nicht höflich genug ist, ist auch nicht menschlich genug" (Grzeczność to kwiat czlowieczeństwa. Kto nie jest wystarczająco grzeczny, nie jest czlowiekiem). Z jednej strony stanowi więc ona ważną podporę w komunikacji, z drugiej jednak utożsamia się ją z nieszczerością.

Lata 70. XX wieku stanowily ważny punkt zwrotny w lingwistyce. Nowe pragmatyczne ujęcie języka jako dzialania, które zapoczątkowali przede wszystkim Austin $(1962 / 1975)$ i Searle $(1969,1975)$ teorią aktów mowy dało możliwość poszerzenia zakresu badań na jak dotąd pomijane bądź niedostatecznie rozważane aspekty języka, w tym między innymi grzeczność językowa, która stala się w ostatnich latach chętnie podejmowanym tematem przez lingwistów, szczególnie na plaszczyźnie kontrastywnej, międzykulturowej. Jednak podanie zadowalającej definicji grzeczności jako obiektu badań lingwistycznych jest bardzo trudne. Niewatpliwie wielka rolę w budowaniu podloża teoretycznego i tworzeniu koncepcji 
grzeczności językowej odegrali tacy badacze jak Grice, Lakoff, Leech, Brown/Levinson czy Fraser.

Amerykański lingwista Paul Grice formuluje „Cooperative Principle” czyli „zasadę kooperacji” oraz cztery maksymy: ilości, jakości, relacji i modalności. Zgodnie z nimi powinno się mówić tyle, ile wymaga tego dany punkt rozmowy, mówić to, co jest ważne, prawdziwe i wyrażać się jasno. Grzeczność odgrywala u Grice'a raczej rolę drugorzędna, gdyż pierwotnie skupił się on na konwersacji jako racjonalnej i efektywnej wymianie informacji, a sama grzeczność wynikala z nieprzestrzegania maksym konwersacyjnych. Niemniej jednak wyróżnia on maksymę grzeczności be polite jako maksymę społeczna, stanowiąca obok maksymy estetycznej i moralnej uzupelnienie maksym konwersacyjnych. W czasie rozmowy zachowuje się co prawda zasadę kooperacji, natomiast może się zdarzyć, że jedna lub więcej maksym nie jest przestrzegana, „a dla badacza zjawiska grzeczności jest to nadzwyczaj cenna uwaga, dotyczy bowiem pewnego rodzaju strategii w dzialaniu językowym, którą można nazwać strategią unikową" (Tomiczek 1992: 119).

LAKOFF podejmuje próbę rozwinięcia myśli Grice'a, wyróżniając dwie zasady kompetencji pragmatycznej: be clear (tu znalazly się maksymy konwersacyjne Grice'a) i be polite, która odgrywa u niej szczególną rolę i dzieli się na kolejne submaksymy: 1. Don 't impose (Nie narzucaj się), 2. Give options (Daj możliwość wyboru) i 3. Make A feel good (Stwórz mile uczucie u partnera rozmowy).

Innym badaczem grzeczności jest Leech, u którego zasada grzeczności polega na minimalizowaniu nieuprzejmości i obejmuje maksymy takie jak maksymę taktu, wspaniałomyślności, aprobaty, skromności, zgody i wspólodczuwania bądź sympatii. Leech dochodzi do wniosku, że te zasady nie są uniwersalne, lecz w różnych kulturach zajmują inne miejsce pod względem ważności (por. Mironovschi 2009: 12).

Dziś powszechnie znana jest teoria grzeczności Brown/Levinson (1978/1987), bazująca na pojęciu twarzy socjologa Goffmana, rozumianej jako image danej osoby, jej obraz w spoleczeństwie. Brown i Levinson wprowadzają pojęcie twarzy pozytywnej, wyrażającej się w chęci do bycia akceptowanym, rozumianym, podziwianym, uzna- 
wanym w spoleczeństwie, a więc posiadania pozytywnego obrazu własnej osoby, oraz twarzy negatywnej, która daży do zachowania dystansu, niezależności, swobody i dowolności dzialania. Opierając się o dwa rodzaje twarzy wyróżniają tzw. grzeczność pozytywna (np. komplementy, czyli dzialania zmierzające ku zaspokojeniu życzeń twarzy pozytywnej) oraz grzeczność negatywnq (osłabianie lub unikanie aktów bezpośrednich, takich jak rozkaz, i tym samym unikanie zagrożeń twarzy). W kontekście tej teorii grzeczność należałoby rozumieć jako zbiór strategii zachowań, których celem jest wzajemne dbanie, szanowanie twarzy nadawcy i odbiorcy, co okazuje się być trudną sztuką z uwagi na fakt, że ,czlowiek może osiagnać swój zamierzony cel częściowo tylko poprzez naruszenie praw do terytorium innych partnerów rozmowy" (Zborowski 2005: 33, thum. V.F.).

Dla Frasera (1990) grzeczność jest rodzajem kontraktu, umowy (CC - Conversational Contract). Wychodzi on z zalożenia, że w interakcji międzyludzkiej istnieje dużo możliwości zachowań, a rozmówcy uzgadniają na początku pewne normy zachowań w oparciu o swoją wiedzę na temat praw, obowiązków i konwencji, które w trakcie rozmowy ulegaja zmianom i są na nowo dostosowywane do sytuacji (por. Werthwein 2009: 32). Grzeczność stanowi zatem swego rodzaju oczekiwaną normę, opartą o niepisaną umowę między nadawcą i odbiorca.

\section{Reakcje na komplement}

Komplementy stanowią powszechną strategię grzecznościowa w życiu codziennym, a ich brak w określonych sytuacjach może być postrzegany wręcz jako niegrzeczność bądź przejaw zazdrości. Różnice kulturowe widoczne są zarówno formulowaniu tych aktów mowy: Tu es un baobab. - przyrównanie czlowieka do baobabu w Kamerunie stanowi komplement „Naprawdę jesteś kimś”, podobne jak Maman tu es une vielle marmite., w którym chwali się kulinarne umiejętności kobiety nazywając ją dosłownie „starym garnkiem", co w kulturze kameruńskiej da się wyjaśnić tym, iż rzekomo potrawy ze starych garnków smakują najlepiej (por. Mulo Farenkia 2004: 54), jak i reagowaniu na nie: 
Pakeha to Samoan friend whom she is visiting.

Sue: What an unusual necklace. It's beautiful./Jaki wyjątko-

wy naszyjnik. Jest piękny.

Eti: Please take it./Proszę, weź go. (Holmes 1995: 120. thum. V.F.)

Komplement i reakcja na niego stanowią sekwencję ściśle ze sobą związaną:

1 A compliments B

2. B responds/acknowledges that A has spoken (Herbert 1989: 5)

Reakcje na komplement można zdefiniować w sposób następujący: „A compliment response is defined as a verbal (and/ or nonverbal V.F.) acknowledgement that the recipient of the compliment heard and reacted to the compliment" (Nelson/Al-Batal/ Echols 1996: 413). Ten akt mowy daje możliwość przyjrzenia się systemowi wartości danego spoleczeństwa.

W niektórych kulturach grzecznym zachowaniem po otrzymaniu komplementu jest podarowanie obiektu komplementowanego nadawcy komplementu (jak w wyżej przytoczonym przykladzie), np. w Chinach komplementy sa odrzucane w ponad 90\%, gdyż niegrzecznie jest je przyjać od razu. Za grzeczną odpowiedź uznaje się w Polsce i Niemczech podziękowanie. Tego typu odpowiedź promowana jest również w poradnikach dobrych manier. Czy znajduje to potwierdzenie w wynikach analizy? Jaki obraz grzeczności wylania się z zebranego materiału?

\section{Analiza}

Przyjrzyjmy się najpierw kilku reakcjom respondentów na komplement z sytuacji nr 1 i 3 oraz grzeczności widzianej ich oczami:

Polscy studenci: 
(1) $\mathrm{K}:{ }^{3}$ Jestem zadowolona, że koleżanka zauważyla moją nową fryzurę. Cieszę się, że innym się podoba, ale podejrzewam, że prawdopodobnie jest trochę zazdrosna, że to na mnie wszyscy zwracają uwagę. Dziękuję jej za komplement. (syt. 1)

(2) K: „Acha, czyli do tej pory wyglądalam okropnie", taka myśl przychodzi mi do głowy. Dziękuję mimo wszystko, ale w głębi duszy jednak mam podejrzenia, że dotychczas niezbyt dobrze wy glądalam... Jednocześnie powinien być to sygnał, że może jednak powinnam coś w sobie zmienić. (syt. 3 )

(3) M: Dziękuję z uprzejmości, ale nie przywiqzuję do tego większej wagi, gdyż jest to tylko koleżanka, a nie moja dziewczyna. (syt. 1)

(4) M: Po raz kolejny wyróżnienie. Podzięlkowalbym, ale zapewne czulbym lekkie skręowanie, ponieważ nie przywykłem do takich komplementów. (syt. 3)

Niemieccy studenci:

(5) K: Ich freue mich darüber und bedanke mich für das Kompliment. (syt. 1)

(6) K: Wundere mich, vielleicht sehe ich sonst nicht gut aus! Denke darüber nach, ob evtl. meine Kleidung sonst nicht so gut aussieht. „Danke.” (syt. 3)

(7) M: Ich würde mich über das ehrliche Kompliment freuen und höflich bedanken - „Danke" (syt. 1)

(8) M: Es wäre mir bei dieser Formulierung eher unangenehm, wenn andere Leute das mithören würden, weil es etwas zu übertrieben klingt. Wenn sie es ernst meint, würde ich mich aber trotzdem freuen und mich bedanken. (syt. 3)

$\mathrm{K}$-kobieta, $\mathrm{M}$-mężczyzna, słowna reakcja-czcionka pogrubiona, kluczowe slowa wyrażające emocje - kursywa. 
Jak wynika z powyższych reakcji, niezależnie od tego, czy komplement wywolal u odbiorcy radość, podejrzenia zazdrości czy też nieszczerości, zdziwienie, skrępowanie, zadowolenie, stanowi wyróżnienie czy krytykę poprzedniego stanu rzeczy, we wszystkich przytoczonych odpowiedziach pojawia się sam akt podziękowania jako werbalna odpowiedź. Studenci dziękuja „,odruchowo w 1. chwili”, ,z uprzejmości” $i$,,mimo wszystko", gdyż etykieta nakazuje prawić komplementy i etykieta nakazuje niejako podziękować za komplement:

(9) Szczerze mówiąc liczę się z tym, że ludzie będą mnie chwalić, bo tak nakazuje etykieta. Wzbudza to jednak podejrzenia, że ktoś jest nieszczery i tylko z uprzejmości tak mówi. $\mathrm{Z}$ drugiej strony jeśli podoba mi się moja fryzura, cieszę się, że podziela moje zdanie. Jeśli wiem, że fryzura mi się podoba, myślę, że chce ona mi sprawić przyjemność. Oczywiście odruchowo w 1. chwili dzięluuję. (syt. 1)

Czy zatem samo „dziękuję" jest najbardziej oczekiwane spolecznie? Czy to oznacza, że we wszystkich czy też w większości zebranych reakcji werbalnych tego typu odpowiedź wystapila? Czy może istnieją pewne odstępstwa? Jeśli tak, czy nadal wpisują się w kategorię grzecznych i akceptowanych odpowiedzi?

Akt podziękowania pojawia się co prawda w większości odpowiedzi na komplement: u niemieckich studentów w 107 na 123 slowne odpowiedzi (87\%), u polskich w 101 na $119(84,9 \%)$, ale co ciekawe tylko w 44,7\% niemieckich i w 54,6\% polskich reakcji wystapil on samodzielnie. Jak widać duży procent odpowiedzi odbiega od tej powszechnie uznawanej za idealną odpowiedź w postaci aktu podziękowania. Zatem muszą istnieć również inne opcje reakcji - zarówno takie, w których podziękowanie nie pojawia się w ogóle, jak i takie, w których nie jest jedyną werbalną reakcja. Czy niezależnie od podejrzeń nieszczerości, czasem również ironii czy szyderstwa respondenci sa w stanie sprostać oczekiwaniom grzecznościowym, uszanować werbalny prezent i nie stanowić zagrożenia dla twarzy? Chyba nie zawsze, o czym świadczą poniższe dwa przykłady: 
(10) K: Akurat, nie udawaj lepiej! Nie lubię szyderczości. (syt. 2)

(11) M: Dobra dobra, weź mi tutaj nie ściemniaj i tak masz mnie w dupie. (syt. 2)

Nie dość, że nie pojawil się tutaj akt podziękowania, to jeszcze z pewnościa tego typu reakcja nie ma zbyt wiele wspólnego z grzecznością: jest bezpośrednim atakiem na twarz osoby komplementującej. Można przypuszczać, że w przypadku sytuacji nr 2 i komplementu od nielubianej osoby pojawią się różnice w sposobie odbioru tego aktu mowy. Pytanie tylko, czy znajdą one w większości przypadków odzwierciedlenie w słownym zachowaniu czy też potencjalne negatywne emocje pozostanąniewypowiedziane. Przyjrzyjmy się zatem kolejnym przykladom reakcji na komplement i sposobom radzenia sobie $z$ dylematem $z$ nimi związanym:

Polscy studenci:

(12) K: Zmartwię się, że chyba źle wyglądam, ale i tak uśmiechnę się i grzecznie podziękuję.

(13) K: Najpierw zastanawiam się, czy to było szczere, czy czasem za tym komplementem nie kryje się jakaś drwina. Ale i tak dziękuję i staram się nawiązać kontakt z tą osoba.

(14) K: Grzecznie dziękuję i uśmiecham się, nie dając po sobie poznać, że danej osoby nie lubię.

(15) M: Dzięluję (bo nie wypada nie podziękować), ale rozmowy nie kontynuuję, oddalam się, itp.

$4 \quad$ Przyklady te dowodza, że negatywna relacja nadawcy i odbiorcy komplementu może mieć decydujący wpływ na sposób reagowania na ten akt mowy. Tego typu odpowiedzi stanowią jednak zdecydowaną mniejszość w zebranym korpusie, podobnie jak stwierdzenie, że relacje łączące rozmówców nie odgry wają znaczącej roli w odbiorze tego aktu mowy: Student: Również dziękuję za komplement. Nie ma dla mnie tak duzego znaczenia, w jakich stosunkach jestem z kimś, kto mnie ocenia. Oczywiście im lepiej się znamy, w tym więsszym stopniu zakladam szczerość i życzliwość. Nie jest to jednak bardzo istotne. (2) 
(16) M: Także cieszę się i dziękuję, jednak zastanawiam się nad przyczyną takiego zachowania / wypowiedzi tej osoby. Być może to ironia/ szyderstwo?

(17) M: Dziękuję za komplement, ale nie traktuję go do końca na poważnie, raczej nieco podejrzliwie, czy może nie ma jakiegoś podtekstu, ironii albo drugiego dna bo pewnie jest.

Niemieccy studenci:

(18) K: Danke für das Kompliment... Gefühle dabei: sagt sie das jetzt, weil sie sich freut, dass ich Scheiße aussehe..., ansonsten hat sie keinen Grund mir Kompliment zu machen.

(19) K: Ich gehe davon aus, dass sie mich täuschen möchte. Bin verunsichert. Sage aber höflich „Danke“6 und wechsle das Thema. Es könnte ja sein, dass sie es ehrlich meint. Kommt auf meine Einschätzung des Charakters der Person an.

(20) M: Ich bin unsicher, ob diese Person es ernst meint, bedanke mich aber trotzdem für das Kompliment.

(21) M: Das Kompliment kommt ganz anders rüber. Ich nehme es nicht wirklich ernst aber bedanke mich trotzdem dafür.

(22) M: Ich bin verwundert und sage einfach nur „Danke $^{66}$.

(23) M: Bin leicht genervt, lasse mir aber nichts anmerken und bedanke mich aus Höflichkeit.

Sytuacja nr 2 różni się od pozostalych relacją nadawca-odbiorca. Okazuje się, że sam akt podziękowania pojawia się najczęściej jako reakcja na komplement od nielubianej osoby: 
Sytuacja nr 1: $\quad$ Polacy $32,3 \%$ Niemcy $23,6 \%$

Sytuacja nr 2: Polacy $46,2 \%$ Niemcy $45,4 \%$

Sytuacja nr 3: Polacy $21,5 \%$ Niemcy $31 \%$

Można zatem wyciagnąć wniosek, że osoby komplementowane ograniczają się $\mathrm{w}$ rozmowie $\mathrm{z}$ nielubianą osobą do pewnego minimum grzecznościowego, czyli slowa „dziękuję”, by uchronić nadawcę i samego siebie przed utratą twarzy, sprostać oczekiwaniom spolecznym oraz nie narażać się na miano osoby niegrzecznej poprzez nieujawnianie prawdziwych emocji (niepewności, zdziwienia, nerwów, podejrzenia szyderstwa ironii itp.). Tylko w nielicznych przypadkach komplement odbierany jest pozytywnie i rozumiany jako próba odbudowy wzajemnych relacji:

(24) Zacznę się zastanawiać $n / t$ jej intencji. Dlaczego to powiedziała? Czy rzeczywiście jej się podoba czy też chce powiedzieć że moje wysilki poszly na marne. Jeśli dojdę do wniosku, że rzeczywiście jej się podoba, to w przyszłości może rozwinę tą przyjaźń. Oczywiście podzięluję. (syt. 2)

W przypadku sytuacji nr 1 i 3 podziękowanie występuje również z innymi elementami, które mają na celu pomniejszenie obiektu komplementowanego czy wywyższenie nadawcy po to, by przywrócić równowage $w$ rozmowie, zrewanżować się milym slowem i wpłynąc pozytywnie na dalsze relacje, zachowując przy tym twarze.

Ciekawą reakcjajest odpowiedź typu wiem, która w calym korpusie pojawila się zaledwie kilka razy: u 9 niemieckich studentów i 1 studentki oraz u 2 polskich studentów i 2 studentek, przykladowo:

(25) K: Dzięki, wiem (czuję, że to szczere i odpowiedź moja jest żartobliwa). (syt. 1)

(26) K: Zwinkernd: „Ich weif(“. (syt. 2) 
(27) M: „Ich weiß * grins* sonst hätte ich sie nicht geändert.“ Bin solche Antworten von ihr gewohnt. Freue mich aber dennoch bestätigt zu werden. (syt. 1)

Wiem pojawia się zarówno samodzielnie jak i w kombinacji z aktem podziękowania czy komentarzem. Studenci zazwyczaj zaznaczali, że ich odpowiedź jest żartobliwa, towarzyszy jej uśmiech i należy ją traktować z przymrużeniem oka. Ten fakt świadczy o tym, że sama reakcja wiem bez dodatkowych werbalnych czy niewerbalnych ,środków lagodzacych” mogłaby być niegrzeczna, wplynać negatywnie na wzajemne relacje i zagrażać twarzom parterów rozmowy:

(28) „Ich weilß.“ Es wăre mir egal was jemand anderer über mein Aussehen denkt.

Odbiorca móglby zostać uznany za osobę nieskromna, zbytnio przekonaną o swojej wartości, natomiast dla nadawcy prawdopodobnie wiązaloby się to $\mathrm{z}$ zagrożeniem twarzy z uwagi na zbędność tego komplementu - nadawca wie o tym, że ladnie wyglada i nie musi otrzymywać tego typu pozytywnego wartościowania.

\section{Podsumowanie}

Analiza korpusu wykazala, że w świetle teorii Brown/Levinson zarówno Polacy jak i Niemcy reagują na komplementy poslugując się działaniami językowymi charakterystycznymi dla grzeczności pozytywnej, zorientowanej na dbanie o twarz pozytywną nadawcy, a więc zgadzaniu się z nim i akceptowaniu jego pozytywnej oceny (u Polaków 70,6\%, u Niemców 69,1\% wszystkich słownych reakcji), wykorzystujac przy tym następujące kombinacje odpowiedzi:

$$
\begin{array}{lll}
\text { dziękuję + komentarz + zgoda } & \text { Niemcy } 4 & \text { Polacy } 1 \\
\text { dziękuję + komentarz } & \text { Niemcy 11 } & \text { Polacy } 10 \\
\text { dziękuję + zgoda } & \text { Niemcy } 7 & \text { Polacy } 4
\end{array}
$$




dziękuję
zgoda + komentarz
zgoda
komentarz $+?^{5}$
komentarz

dziękuję

zgoda + komentarz

zgoda

komentarz

$\begin{array}{ll}\text { Niemcy } 55 & \text { Polacy } 65 \\ \text { Niemcy } 2 & \text { Polacy } 2 \\ \text { Niemcy } 2 & \text { Polacy 1 } \\ \text { Niemcy } 1 & \text { Polacy 0 } \\ \text { Niemcy } 3 & \text { Polacy 1 }\end{array}$

Z pewnością wszelkiego rodzaju reakcje, które można by zakwalifikować do kategorii odrzucenia komplementu, nie stanowia typowej grzecznościowej strategii (zaledwie 5,7\% u Niemców i $6,7 \%$ u Polaków).

Boller powiedział kiedyś „Ein Kompliment ist der Sieg der Höflichkeit über die Ehrlichkeit ${ }^{\star " 6}$. Przytoczone w artykule przyklady pozwalają na analogiczne stwierdzenie w kontekście reagowania na ten akt mowy. Tak więc można stwierdzić, że zarówno u Polaków jak i Niemców zachowania językowe determinowane są w większej mierze spolecznie akceptowanymi, uznawanymi i oczekiwanymi normami grzecznościowymi, a wzajemne szanowanie twarzy respondentów odgrywa jak widać kluczową rolę:

M: Ich wundere mich und fühle mich verarscht. Höflich bedanke ich mich. (syt. 2)

\section{Bibliografia}

Herbert, Robert (1989): „The ethnography of English compliments and compliment responses: A contrastive sketch." [w:] Oleksy, Wiesław (red.): Contrastive Pragmatics. Amsterdam: John Benjamins, 3-35.

Holmes, Janet (1995): Women, Men and Politeness. London, New York: Longman.

Marcjanik, Malgorzata (1992): , Typologia polskich wyrażeń językowych o funkcji grzecznościowej”. [w:] Anusiewicz, Janusz/Marcjanik,

5 Tym symbolem oznaczone zostały takie reakcje respondentów jak np.: Serio? Naprawdę? Poważnie?

6 http://www.gutzitiert.de/zitat_autor_ralph_boller_thema_kompliment_ zitat_12584.html (15.09.2010). 
Malgorzata (red.): Język a kultura. Tom 6. Polska etykieta językowa. Wroclaw: Wiedza o Kulturze, 27-32.

Mironovschi, Lilia (2009): Komplimente und Komplimenterwiderungen im Russischen und im Deutschen: ein interkultureller Vergleich. Frankfurt/M., Berlin i in.: Lang.

Mulo Farenkia, Bernard (2004): Kontrastive Pragmatik der Komplimente und Komplimenterwiderungen. Aachen: Shaker.

Nelson, Gayle/Al-Batal, Mahmoud/Echols, Erin (1996): "Arabic and English compliment responses: Potential for pragmatic failure". [w:] Applied Linguistics 17 (4), 411-432.

Tomiczek, Eugeniusz (1991): „Z badań nad istota grzeczności językowej”. [w:] Anusiewicz, Janusz/Marcjanik, Malgorzata (red.): Język a kultura. Tom. 6. Polska etykieta jezykowa. Wroclaw: Wiedza o Kulturze, 1525.

Werthwein, Daniela Christina (2009): Already got a compliment today? Wie Australier und Deusche verbal auf Komplimente reagieren. Sankt Augustin: Asgard.

Zborowski, Piotr (2005): Dankbarkeit vs. Höflichkeit und sprachliche Routine. Der Dankakt im Schwedischen verglichen mit Polnisch und Deutsch. Poznań: Wydawnictwo Naukowe UAM.

\section{Źródla internetowe}

http://www.gutzitiert.de/zitat_autor_ralph_boller_thema_kompliment zitat_12584.html (15.09.2010) 